\title{
Soft news/tabloidization (Journalistic Reporting Styles)
}

\section{AUTHOR}

Miriam Steiner

\section{KEYWORDS}

infotainment, sensationalism, tabloid media, hard news, media performance

\section{BRIEF DESCRIPTION}

The concept of "softening the news" or "tabloidization" refers to the adaption of tabloid standards by elite media, as a result of competitive pressures and with the aim of attracting the attention of the mass audience (e.g., Magin, 2019). Reinemann et al. (2012) distinguish three important dimensions:

1. topic dimension: According to this dimension, "soft news" can be distinguished from "hard news" by their political relevance; one can either determine the level of political relevance (Reinemann et al., 2012) or - as most studies do (e.g., Steiner, 2016) - distinguish between topics that can be classified as either hard (e.g., politics) or soft (e.g., crime, sports, lifestyle).

2. focus dimension: Soft news in this respect reports on issues in a rather episodic and less thematic way which means that the news coverage focuses more on the event itself instead of framing the event in a more general context (see also Entman, 1993; Iyengar, 1991). Furthermore, soft news rather focuses on individual rather than societal consequences.

3. style dimension: According to this dimension, soft news can be distinguished from hard news by the way of presentation. Soft news is presented inter alia in a more emotional, subjective or narrative way.

News softening therefore represents a multi-di- mensional concept (Esser, 1999; Reinemann et al., 2012) in which the different dimensions and indicators form a continuum. On this basis one can assess the degree of overall news softening. The concept thereby incorporates various other concepts of communication science (e.g., framing, subjective/objective reporting, etc.) and can thus be also attributed to distinct research traditions. Particularly in the style dimension, many different indicators are analysed - although studies often differ as to which indicators are used.

\section{FIELD OF APPLICATION/THEORETICAL FOUNDATION} Since soft news journalism is often seen as a threat to normative standards for quality media, research on soft news and tabloidization trends is often part of studies on media performance. So far, studies on news softening and tabloidization focus on the comparison of (elite and popular) newspapers (e.g., Lefkowitz, 2018) or (public service and commercial) TV newscasts (e.g., Donsbach \& Büttner, 2005). More recent studies also take online media into account (e.g., Karlsson, 2016) or compare social media platforms such as Facebook with offline and/or online media (e.g., Lischka \& Werning, 2017; Magin et al., 2021).

\section{REFERENCES/COMBINATION WITH OTHER METHODS OF DATA COLLECTION}

Content analyses can be combined with survey data from/ interviews with journalists (e.g., Leidenberger, 2015; Lischka \& Werning, 2017; Lischka, 2018) or with experiments on the effect of soft news on the audience (e.g., trust in the news, information processing: see Bernhard, 2012 or Grabe et al., 2003 as examples, although these studies do not combine the results on the effects with content analyses). 
Table 1. Example studies.

\begin{tabular}{|c|c|c|}
\hline Indicator & Name of variable(s) & Study \\
\hline \multicolumn{3}{|l|}{ Topic Dimension: } \\
\hline Political relevance & Political relevance & Reinemann et al., 2012 \\
\hline Topic & $\begin{array}{l}\text { Thema (kategorisiert) [topic (catego- } \\
\text { rized)] }\end{array}$ & Steiner, 2016 \\
\hline \multicolumn{3}{|l|}{ Focus Dimension: } \\
\hline Episodic framing & Episodic - thematic framing & Reinemann et al., 2012 \\
\hline Individual framing & Individual - societal relevance & Reinemann et al., 2012 \\
\hline \multicolumn{3}{|l|}{ Style Dimension: } \\
\hline $\begin{array}{l}\text { 1. Emotional reporting (incl. } \\
\text { affective wording, visual pre- } \\
\text { sentation of emotions) }\end{array}$ & Emotional - unemotional reporting & Reinemann et al., 2012 \\
\hline 2. Personal reporting & Personal - impersonal reporting & Reinemann et al., 2012 \\
\hline 3. Colloquial/ loose language & $\begin{array}{l}\text { Umgangssprache, Lockerheit der } \\
\text { Sprache [colloquial, loose language] }\end{array}$ & Steiner, 2016 \\
\hline 4. Narrative presentation & $\begin{array}{l}\text { Nachrichtenpyramide vs. Narration } \\
\text { [news pyramid vs. narration] }\end{array}$ & $\begin{array}{l}\text { Donsbach \& Büttner, } \\
2005\end{array}$ \\
\hline 5. Emphasis on conflicts & Konflikthaltigkeit [conflicts] & $\begin{array}{l}\text { Donsbach \& Büttner, } \\
2005\end{array}$ \\
\hline
\end{tabular}

\section{Topic Dimension}

With respect to the topic dimension, soft and hard news can be determined either by the extent to which the political relevance is made clear within the article (e.g., Reinemann et al., 2012) or by the distinction between topics (e.g., Steiner, 2016). Most studies use the latter option with politics (and sometimes economics as well) being considered hard news and topics such as sports and celebrity news being considered soft news.

Topic Dimension, Indicator 1: political relevance (Reinemann et al., 2012) 


\section{INFORMATION ON REINEMANN ET AL., 2012}

Authors: Carsten Reinemann, James Stanyer, Sebastian Scherr, Guido Legnante

Research question: This study is a meta-analysis that wants to find out 1) how different studies define news softening and 2) which dimensions and indicators are most often used to measure news softening. As a result, the paper suggests three important dimensions (topic, focus, style) and concrete indicators and operationalizations to measure these dimensions.

Object of analysis: 24 studies

\section{INFO ABOUT VARIABLE}

"Four aspects are distinguished that indicate the degree of political relevance of a news item: (1) societal actors, (2) decision-making authorities, (3) policy plan and (4) actors concerned. For each of those aspects the presence (1) or non-presence (0) is coded." (Reinemann et al. 2012, p. 237)

1. "Two or more societal actors that disagree on a societal issue (e.g., two parties, a party and an NGO, voters and politicians, employers and trade unions).

2. Decision-making authorities (legislative, executive, judiciary) that are or could be involved in the generally binding decision about that societal issue.

3. The substance of a planned or realized decision, measure, programme that relates to the issue.

4. The persons or groups concerned by the planned or realized decisions, measures, programmes." (Reinemann et al., 2012, p. 237)

Variable name: political relevance

Level of analysis: article

Values: 0) not present; 1) present

Level of measurement: nominal

Reliability: Variable was not tested within this study.

Codebook (in the appendix of the paper, p. 237-238) available under: DOI: 10.1177/1464884911427803

Topic Dimension, Indicator 2: topic (Steiner, 2016)

INFORMATION ON STEINER, 2016

Author: Miriam Steiner

Research question: The study investigates the news softening of German public service and commercial political news on TV and on Face- book.

Object of analysis: ARD Tagesschau (TV); ZDF heute (TV); Sat.1 Nachrichten (TV); RTL Aktuell (TV); ARD Tagesschau (Facebook); ZDF heute (Facebook); Sat.1 Nachrichten (Facebook); RTL Aktuell (Facebook)

Time frame of analysis: artificial week in 2014 (April, 10 - October, 10)

\section{INFO ABOUT VARIABLE}

Variable name: Thema (kategorisiert)/ Ressort [Topic (categorized)/ (newspaper) section]

Level of analysis: article

Values (in German):

- 101-247) Politik [politics]; 310-399) Wirtschaft [economics] $\rightarrow$ defined as "hard news"

- 900) Unfall/Katastrophe [accident, catastrophe]; 1000-1010) Kriminalität [crime]; 1100) human interest; 1200) Sport [sports] $\rightarrow$ defined as "soft news"

Level of measurement: nominal

Reliability: one coder; intra-coder-reliability: 0.81 (Krippendorff's Alpha), 83.3\% (Holsti)

Codebook attached (in German)

\section{Focus Dimension}

According to this dimension, hard and soft news can be distinguished by the framing of the article. Reinemann et al. (2012) hereby differentiate between 1) episodic (soft) vs. thematic (hard) framing and 2) individual (soft) vs. societal (hard) framing.

Focus Dimension, Indicator 1: episodic vs. thematic framing (Reinemann et al., 2012: for information about the study, see above)

"Here, the focus of a news item as related to the accentuation of episodes or themes is coded. Episodically focused news items present an issue by offering a specific example, case study, or event oriented report, e.g., covering unemployment by presenting a story on the plight of a particular unemployed person [...]" (Reinemann et al. 2012, p. 238)

Variable name: episodic - thematic framing Level of analysis: article

Values: 0) pure or predominant episodic framing; 1) mixed episodic and thematic framing; 2) pure or predominant thematic framing

Level of measurement: ordinal 
Reliability: Variable was not tested within this study.

Codebook (in the appendix of the paper, p. 237-238) available under: DOI: 10.1177/1464884911427803

Focus Dimension, Indicator 2: individual vs. societal framing

(Reinemann et al., 2012: for information about the study, see above)

"Here, the focus of a news item as related to the accentuation of personal or societal relevance is coded. Individually focused news stress [sic!] the personal, private meaning or consequences of the incidents, developments, decisions etc. reported about for members of society. [...]" (Reinemann et al. 2012, p. 237)

Variable name: individual - societal relevance Level of analysis: article

Values: 0 ) pure or predominant focus on individual relevance/ consequences; 1 ) mixed attention to individual and societal relevance/ consequences; 2) pure or predominant focus on societal relevance/ consequences

Level of measurement: ordinal

Reliability: Variable was not tested within this study.

Codebook (in the appendix of the paper, p. 237-238) available under: DOI: 10.1177/1464884911427803

\section{Style Dimension}

This dimension is about how news is presented. Studies thereon analyse different indicators with 1) emotional reporting being most frequently used. Besides, studies refer to 2) personal reporting (i.e., the presence of the journalist's point of view), 3) colloquial/ loose language, 4) narrative presentation or 5) emphasis on conflicts as indicators of a soft news style.

Style Dimension, Indicator 1: emotional reporting Most studies measure emotional reporting with the help of only one variable (usually a multi-level scale) (e.g., Reinemann et al., 2012). Alternatively, one can further distinguish (Magin \& Stark, 2015) between verbal style (linguistic features such as strong adjectives and superlatives or emotional metaphors) and visual style (showing emotions in pictures) (e.g., Leidenberger, 2015).

Style Dimension, Indicator 1: emotional reporting (Reinemann et al., 2012: for information about the study, see above)
"Here, the journalistic style of a news item as related to the emotional presentation of information is coded. [...] Emotional news items use verbal, visual or auditive means that potentially arouse or amplify emotions among audience members. This can be done, for example, (a) by dramatizing events, i.e. presenting them as exceptional, exciting, or thrilling; (b) by affective wording and speech, e.g. superlatives, strong adjectives, present tense in the description of past events, pronounced accentuation; (c) by reporting on or visually presenting explicit expressions of emotions (e.g., hurt, anger, fear, distress, joy). [...]" (Reinemann et al. 2012, p. 238)

Variable name: emotional - unemotional reporting

Level of analysis: article

Values: 0 ) purely or predominantly emotional; 1 ) mix of emotional and unemotional elements; 2) purely or predominantly unemotional

Level of measurement: ordinal

Reliability: Variable was not tested within this study.

Codebook (in the appendix of the paper, p. 237-238) available under: DOI: 10.1177/1464884911427803

Style Dimension, Indicator 2: personal reporting (Reinemann et al., 2012: for information about the study, see above)

"Here, the journalistic style of a news item as related to the explicit appearance of journalists' personal points of view is concerned. It is coded whether a news item includes explicit statements of the reporting journalists' personal impressions, interpretations, points of view or opinions. [...]" (Reinemann et al. 2012, p. 238)

Variable name: personal - impersonal reporting Level of analysis: article

Values: 0 ) purely or predominantly personal; 1 ) mix of personal and impersonal elements; 2) purely or predominantly impersonal

Level of measurement: ordinal

Reliability: Variable was not tested within this study.

Codebook (in the appendix of the paper, p. 237-238) available under: DOI: 10.1177/1464884911427803

Style Dimension, Indicator 3: colloquial/ loose language

(Steiner, 2016: for information about the study, see above) 
The variable measures the degree of colloquial language on a 3-point-scale, ranging from 0 (not colloquial at all) to 2 (very colloquial).

Variable name: Umgangssprache/ Lockerheit der Sprache [colloquial/ loose language]

Level of analysis: article

Values (in German): 0) gar nicht umgangssprachlich; 1) wenig umgangssprachlich; 2) stark umgangssprachlich

Level of measurement: ordinal

Reliability: one coder; intra-coder-reliability: 0.72 (Krippendorff's Alpha, interval), 88.9\% (Holsti, nominal)

Codebook attached (in German)

Style Dimension, Indicator 4: narrative presentation

(Donsbach \& Büttner, 2005)

\section{INFORMATION ON DONSBACH \& BÜTTNER, 2005}

Authors: Wolfang Donsbach, Katrin Büttner

Research question: The study examines the presentation of political news coverage in the most important public service and commercial main German newscasts in 1983, 1990 and 1998 with the aim of revealing changes in the presentation of politics and the extent to which there are convergent trends ( $\rightarrow$ tabloidization).

Object of analysis: news on politics within four German newscasts: Tagesschau (ARD), ZDF heute, Sat.1 Blick/18.30, RTL Aktuell (in 1983: only Tagesschau and ZDF heute)

Time frame of analysis: for each year, every second day within the last four weeks before election day was analysed: 1) February 7, 1983 to March 6, 1983 (March 6, 1983 = election day); 2) November 5, 1990 to December 2, 1990 (December 2, $1990=$ election day); 3) August 31, 1998 to September 27, 1998 (September 27, 1998 = election day)

\section{INFO ABOUT VARIABLE}

This variable is used to measure whether news is presented in terms of the "inverted news pyramid" (that is, answering the important W-questions at the beginning) or whether the journalist tells a story. This variable is measured on a 5-point-scale ranging from -2) (news pyramid) to 2) narration.

Variable name: Nachrichtenpyramide vs. Narration [news pyramid vs. narration]

Level of analysis: article

Values (in German): -2) Nachrichtenpyramide; -1);
0) weder/noch; 1); 2) narrativ

Level of measurement: ordinal

Reliability: four coders, reliability: N.A.

Codebook (in German) available under:

http://donsbach.net/wp-content/up-

loads/2011/12/Codebuch_TV-Nachrichten.pdf

Style Dimension, Indicator 5: emphasis on conflicts (Donsbach \& Büttner, 2005: for information about the study, see above)

The variable measures whether conflicts are mentioned or not $(=9)$. The variable also distinguishes between implicit ( $=1$; conflict is apparent, but not openly addressed) and explicit (=2; conflict is openly addressed) conflicts.

Variable name: Konflikthaltigkeit [conflicts]

Level of analysis: article

Values (in German): 1) impliziter Konflikt; 2) expliziter Konflikt; 9) kein Konflikt

Level of measurement: nominal

Reliability: four coders, reliability: N.A.

Codebook (in German) available under:

http://donsbach.net/wp-content/up-

loads/2011/12/Codebuch_TV-Nachrichten.pdf

\section{REFERENCES}

Bernhard, U. (2012). Infotainment in der Zeitung: Der Einfluss unterhaltungsorientierter Gestaltungsmittel auf die Wahrnehmung und Verarbeitung politischer Informationen [Infotainment in the newspaper: The influence of entertainment-oriented style elements on the perception and processing of political information]. Baden-Baden: Nomos.

Donsbach, W., \& Büttner, K. (2005). Boulevardisierungstrend in deutschen Fernsehnachrichten [Tabloidization trend in German TV news]. Publizistik, 50(1), 21-38.

Entman, R. M. (1993). Framing: Toward clarification of a fractured paradigm. Journal of Communication, 43(4), 51-58.

Esser, F. (1999). 'Tabloidization' of news: A comparative analysis of Anglo-American and German press journalism. European Journal of Communication, 14(3), 291-324.

Grabe, M. E., Lang, A., \& Zhao, X. (2003). News content and form: Implications for memory and audience evaluations. Communication Research, 30(4), 387-413.

Iyengar, S. (1991). Is anyone responsible? How television frames political issues. Chicago: University of Chicago Press. 
Karlsson, M. B. (2016). Goodbye politics, hello lifestyle. Changing news topics in tabloid, quality and local newspaper websites in the U.K. and Sweden from 2002 to 2012. Observatorio, 10(4), 150-165.

Lefkowitz, J. (2018). “Tabloidization” or dualconvergence: Quoted speech in tabloid and "quality" British newspapers 1970-2010. Journalism Studies, 19(3), 353-375.

Leidenberger, J. (2015). Boulevardisierung von Fernsehnachrichten: Eine Inhaltsanalyse deutscher und französischer Hauptnachrichtensendungen [Tabloidization of TV news: A content analysis comparing German and French main newscasts]. Wiesbaden: VS.

Lischka, J. A. (2021). Logics in social media news making: How social media editors marry the Facebook logic with journalistic standards. Journalism, 22(2), 430-447.

Lischka, J. A., \& Werning, M. (2017). Wie Facebook den Regionaljournalismus verändert: Publikums- und Algorithmusorientierung bei der Facebook-Themenselektion von Regionalzeitungen [How Facebook alters regional journalism: Audience and algorithm orientation in the Facebook topic selection of regional newspapers]. kommunikation@gesellschaft, 18.

Magin, M. (2019). Attention, please! Structural influences on tabloidization of campaign coverage in German and Austrian elite newspapers (1949-2009). Journalism, 20(12), 1704-1724.

Magin, M., \& Stark, B. (2015). Explaining national differences of tabloidisation between Germany and Austria. Journalism Studies, 16(4), 577-595.

Magin, M., Steiner, M., Häuptli, A., Stark, B., \& Udris, L. (2021). Is Facebook driving tabloidization? A cross-channel comparison of two German newspapers. In M. Conboy \& S. A. Eldridge II (Eds.), Global Tabloid: Culture and Technology (pp. 56-74). London, New York: Routledge.

Reinemann, C., Stanyer, J., Scherr, S., \& Legnante, G. (2012). Hard and soft news: A review of concepts, operationalizations and key findings. Journalism, 13(2), 221-239.

Steiner, M. (2016). Boulevardisierung goes Facebook? Ein inhaltsanalytischer Vergleich politischer Nachrichten von tagesschau, heute, RTL Aktuell und Sat.1 Nachrichten im
Fernsehen und auf Facebook [Tabloidization goes Facebook? A comparative content analysis of the news quality of tagesschau, heute, RTL Aktuell and Sat.1 on TV and on Facebook]. In L. Leißner, H. Bause \& L. Hagemeyer (Eds.), Politische Kommunikation - neue Phänomene, neue Perspektiven, neue Methoden (pp. 27-46). Berlin: Frank \& Timme. 